\title{
PRELIMINARY MINERALOGICAL AND CHEMICAL PROPERTIES OF HALITE IN THE SOUTH OF TUZGÖLÜ BASIN (TURKEY)
}

DOI: http://dx.doi.org/10.18509/GBP.2017.04

UDC: 553.63:549.451.1.04(560)

\author{
Hatice Ercan ${ }^{1,2}$ \\ Muazzez Çelik Karakaya ${ }^{1}$ \\ Necati Karakaya ${ }^{1}$ \\ Ayla Bozda $\breve{g}^{1}$ \\ Arif Delikan ${ }^{1}$ \\ ${ }^{1}$ Selçuk University Engineering Faculty Geology Engineering, Konya, 42079, Turkey \\ ${ }^{2}$ Istanbul Technical University, Department of Geology, 34469, Istanbul, Turkey
}

\begin{abstract}
The study area is located in the southern parts of Tuzgölü basin namely closed Konya basin, which is one of the largest inner/closed basin of Neogene age in the Central Anatolia (Turkey). The basin was mostly filled with the Late Cretaceous-Quaternary aged different types of minerals. The basin, in deep, starts red colored clastic sediments which are formed from thick red clastic unit was deposited in shallow-deep-shallow marine environments. This study was primarily focused on the textural properties of halite mineral in the Miocene units. The textural properties of the halite mineral have been investigated mainly for detection of environmental conditions and origin of halites as primary and secondary halites. Remnant of chevrons structures are most common primary texture preserved in ancient halite deposits. Upward-growing chevrons determined in the halite minerals show that these textures contain rich fluid inclusions and have cloudy or milky appearance. Halite minerals are interlayered with carbonate, sulfate and clay minerals in the studied core samples. The halite layers are generally observed in thick of $\mathrm{mm}-\mathrm{dm}$, salt deposits in the $\mathrm{dm}-\mathrm{m}$ in size precipitated when condition are suitable that huge thickness of shoal water evaporite can accumulate in very short time frames. The thin laminates of halite indicate the fluid chemistry causing the precipitation and changed in a short time interval of the environment condition. The presence of hoper-textures in halite minerals indicated that the first precipitated on the shallow hyper saline brine pools and when they were undisturbed by wind and waves. The secondary marks were commonly observed in the drillings as the nodular structure anhydrite and mosaic texture of halite. The ratios of $\mathrm{Cl} / \mathrm{Br}$ and $\mathrm{Na} / \mathrm{Br}$ in the studied halite samples have very high values that are in relation to dissolution and mixing.
\end{abstract}

Keywords: Halite, Tuzgölü, hopper texture, evaporation, $\mathrm{Cl} / \mathrm{Br}$ ratio

\section{INTRODUCTION}

The study area is located in the southern part of closed Konya basin, which is one of the largest sedimentary basins of Neogene age in the Central Anatolia, Turkey (Figure 1). In this study, evaporite minerals which have been obtained from the drillings made from the Miocene aged evaporates, have been investigated. Carbonates, gypsum, anhydrite and halite minerals have been identified and they are usually accompanied glauberite and clay 
minerals. The salts (mostly halite or $\mathrm{CaSO}_{4}$ ) precipitated by evaporation, in a brine pan environment, forms after the precipitation of the alkaline earth carbonates. This study was primarily focused on the textural properties of halite mineral. The crystal texture of the precipitated salts gives important clues about the chemistry of the brine which caused the precipitation, medium, temperature and depth

Gypsum and anhydrite minerals which have been detected from the drillings show different structural and textural differences. Studies have shown that $\mathrm{cm}$ or $\mathrm{dm}$ size aligned bottom-nucleated crystals reflect widely shallow water environments. The first crystals formed in the shallow brine environment are halite chevrons and aligned gypsum crystals. In deeper brine environment, silt-sized pelagic deposits or as a mass of coarsely crystalline monomineralic bottom meshwork can be observed [1].

The textural properties of the halite mineral have been used mainly for the detection of primary and secondary halites. The halite precipitated in the form of chevrons, cubes and hopper-shaped on the surface and shallow hypersaline brine pools. Remnant of chevrons structures are most place primary texture preserved in ancient halites. Upward-growing chevrons determined in the halite minerals show that these textures contain rich fluid inclusions and have cloudy or milky appearance. The clear and spar-like crystals are secondary and such textures are very important in determining primary and secondary halites. The effect of diagenesis usually causes mosaic texture in the halite mineral, and ancient bedded halite deposits are dominated by mosaic textures [2]. Hopper and raft textures forms air-brine interface, and rafts grow until the crystal mass becomes heavy surface tension, and sinks to bottom. Raft and other cumulate crystals textures indicate very shallow ephemeral brine pans [3].

Thick halite (rocksalt) layers detected in the studied drillings may include gypsum, anhydrite and glauberite interlayers, and as well carbonate minerals. Na-sulphate- $\mathrm{NaCl}$ ions are generally used to interpret the evaporitic properties of the basin [4]. Evaporite mineral assemblages are among the best clue of paleo-fluid chemistry and an understanding of evaporite geochemistry at Tuz Gölü Basin. Also, it is very difficult to determine the chemistry of the primary solution in the evaporation environment due to the complex physical and chemical nature of the sedimentary rocks at this basin. Chloride $(\mathrm{Cl})$ and bromide $(\mathrm{Br})$ ions are unique solutes in all natural water. The major reservoir of water (the ocean) has relatively uniform $\mathrm{Cl}$ and $\mathrm{Br}$ concentrations and their $\mathrm{Cl} / \mathrm{Br}$ molar ratio is around $655 \pm 4$ [5]. The $\mathrm{Cl} / \mathrm{Br}$ ratio has been used as a tracer to determine the origin and evolution of groundwater, surface water and brines in oil and gas exploration [6].

The aim of this paper is (1) to determine the mineralogical composition of the deposited sediments (2) to interpret the paleo-environment, (3) morphological properties of the paleo-fluids.

\section{GEOLOGY}

The Tuz gölü Basin is located in western part of the Central Anatolia. The basin was filled with the Late Cretaceous-Quaternary sediments with a measurable thickness of $5000 \mathrm{~m}$ (Figure 1). The basin, in deep, starts red colored clastics which are a terrestrial unit; in above this red clastic unit a thick sequence was deposited in shallow-deep-shallow marine environments [7]. The Tuz Gölü fault comprise an elevated $(>1000 \mathrm{~m})$ low relief $(<300$ m) plateau between the Aegean extensional province to the west and the ArabianAnatolian continental collision zone to the east. The fault systems are generally characterized by normal faults with some strike-slip components in the Central Anatolia 
[8]. These fault systems have generated numerous fault-controlled basins (horsts and grabens), this morphology is typically interrupted by conical volcanic mountains (Figure 1). The main Plio-Quaternary volcanic eruption centers are strato-volcanoes at the southern part of the plateau linked to shallow asthenosphere characterized by lowvelocity band beneath Central Anatolia ([9] and [10].

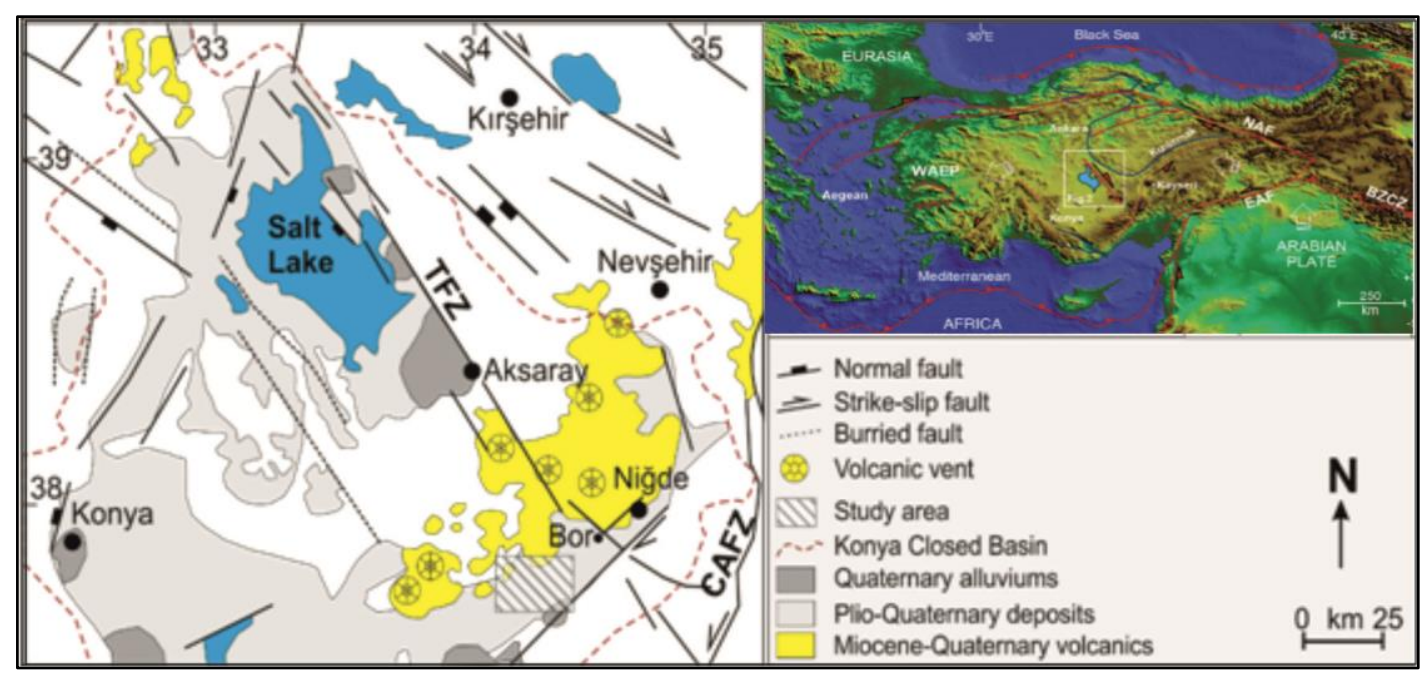

Figure 1. Simplified geology map and location map (After [11] and [8]).

\section{RESULTS}

The primary structures and textures in evaporite sediments were not entirely preserved. Recrystallization, replacement and deformation as depositional processes are quite effective within the basin. Many evaporite minerals have been altered by recrystallization or re-placement without destruction of the primary macro-micro structures under the influence of these process. During this process, the primary structures of the minerals completely altered to secondary textures, or partially altered, and primary textures were preserved in part.

Based on the petrographically and mineralogical data obtained by some investigation methods (X-ray diffraction, optic and scanning electron microscopic) and correlations of ten drillings it is concluded that the precipitation of halite increases in the northern part of the basin while it decreases in the south may be indicating that there is a flowing of groundwater from the south to the basin.

Evaporation minerals e.g., carbonate, sulphate and halite have been identified in the study area. These minerals are usually accompanied with autogenetic and/or detrital silicate minerals, e.g. quartz, feldspar, mica, clay, and rarely zeolite minerals. The salts (mostly halite) and/or sulphates precipitated by evaporation, in a brine pan environment, forms after the precipitation of the alkaline earth carbonates (Figure 2). Halite minerals are interlayered with carbonate, sulphate and clay minerals in the basin. The halite layers are generally observed in thick of $\mathrm{mm}-\mathrm{dm}$, salt deposits in the $\mathrm{dm}-\mathrm{m}$ in size precipitated when condition are suitable that huge thickness of shoal water evaporite can accumulate in very short time frames. The thin laminates of halite indicate the fluid chemistry causing the precipitation and changed in short time intervals of the environment condition. 


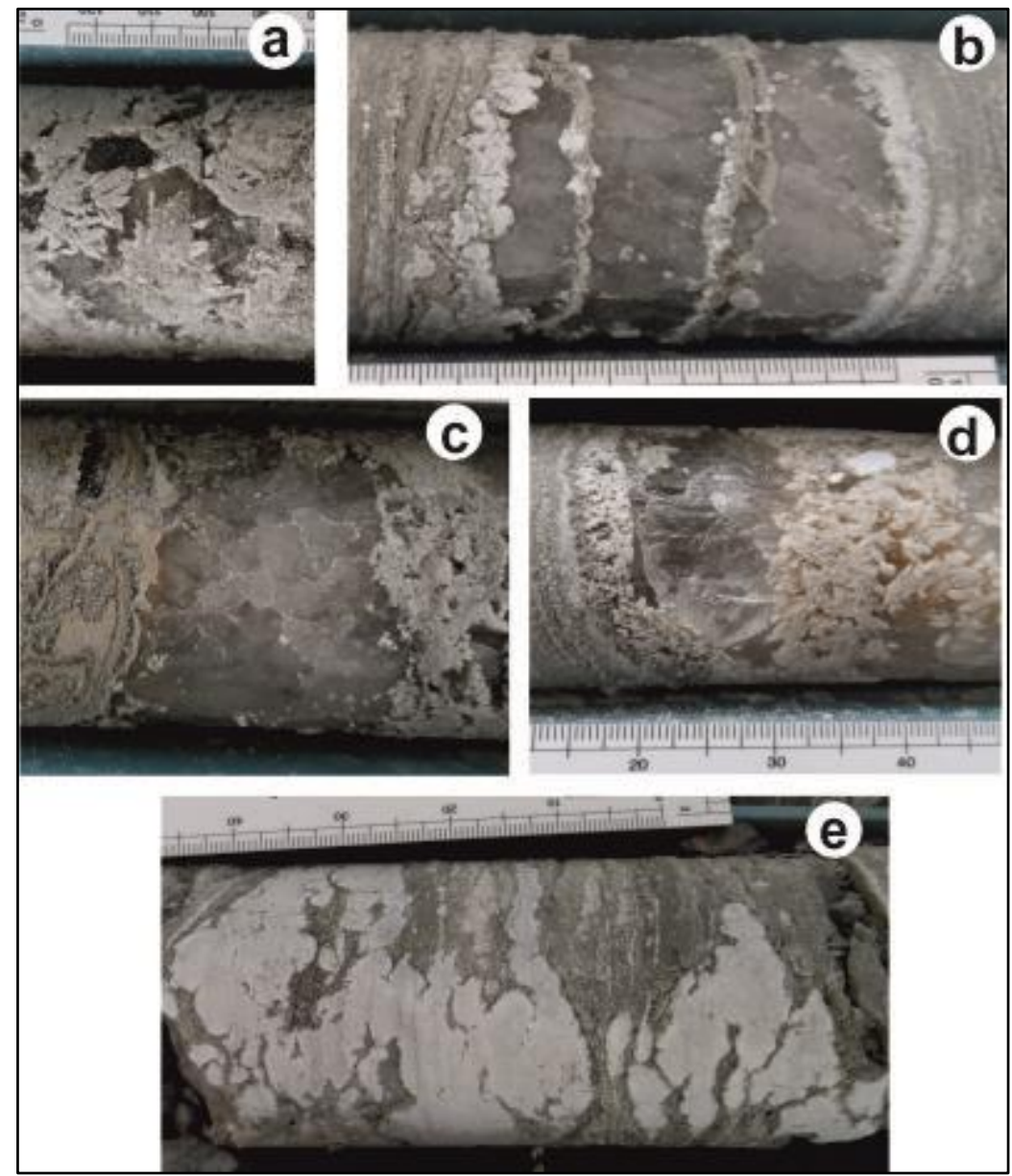

Figure 2. a) Euhedral glauberite, b) intercalation of halite, anhydrite, carbonate and aligned halite crystals, c) mosaic halite, d) halite and euhedral glauberite, e) anhydrite nodules

According to the thin sections investigation of core samples, it is detected that $\mathrm{cm}$ in size aligned nucleated crystals are recognized shoal water textures. Depending on brine salinity of the precipitating bottom-nucleated unit was typically composed of halite chevrons and aligned gypsum crystals (Figure 3 and 4). The halite precipitated in the form of chevrons, cubes and hopper-shaped on the surface and shallow hyper saline brine pools. Remnant of chevrons structures are most commonplace primary texture preserved in ancient halites. Upward-growing chevrons determined in the halite minerals show that these textures are enriched by fluid inclusions and have cloudy or milky appearance. The clear and spar-like crystals are secondary and such textures are very important in determining primary and secondary halites. The amount of fluid inclusion decreased towards the surface to the deep due to diagenesis. In deeper waters, crystals are typically silt-sized gypsum and layered halite minerals. The presence of hoper-textures in halite minerals indicated that the first precipitated on the shallow hypesaline brine pools and when they were undisturbed by wind and waves. Hoppers can raft as raft held at the airbrine interference. Rafts are sinks when the crystal mass becomes heavy than surface tension. In the all depths of the cores, it has been detected that primary textures accompanying with secondary textures. Fluid inclusions in halite minerals were determined as primary fluid inclusions parallel to the growth traces and as secondary inclusions locating perpendicular to the growth traces. Some of the inserts are round and ellipsoidal, while others are cubic. These eutectic inclusions in the salt crystals formed in 
the solution contact with the air, and they are formed by submerging the crystals which reach to a certain weight and size in the form of cumulate.

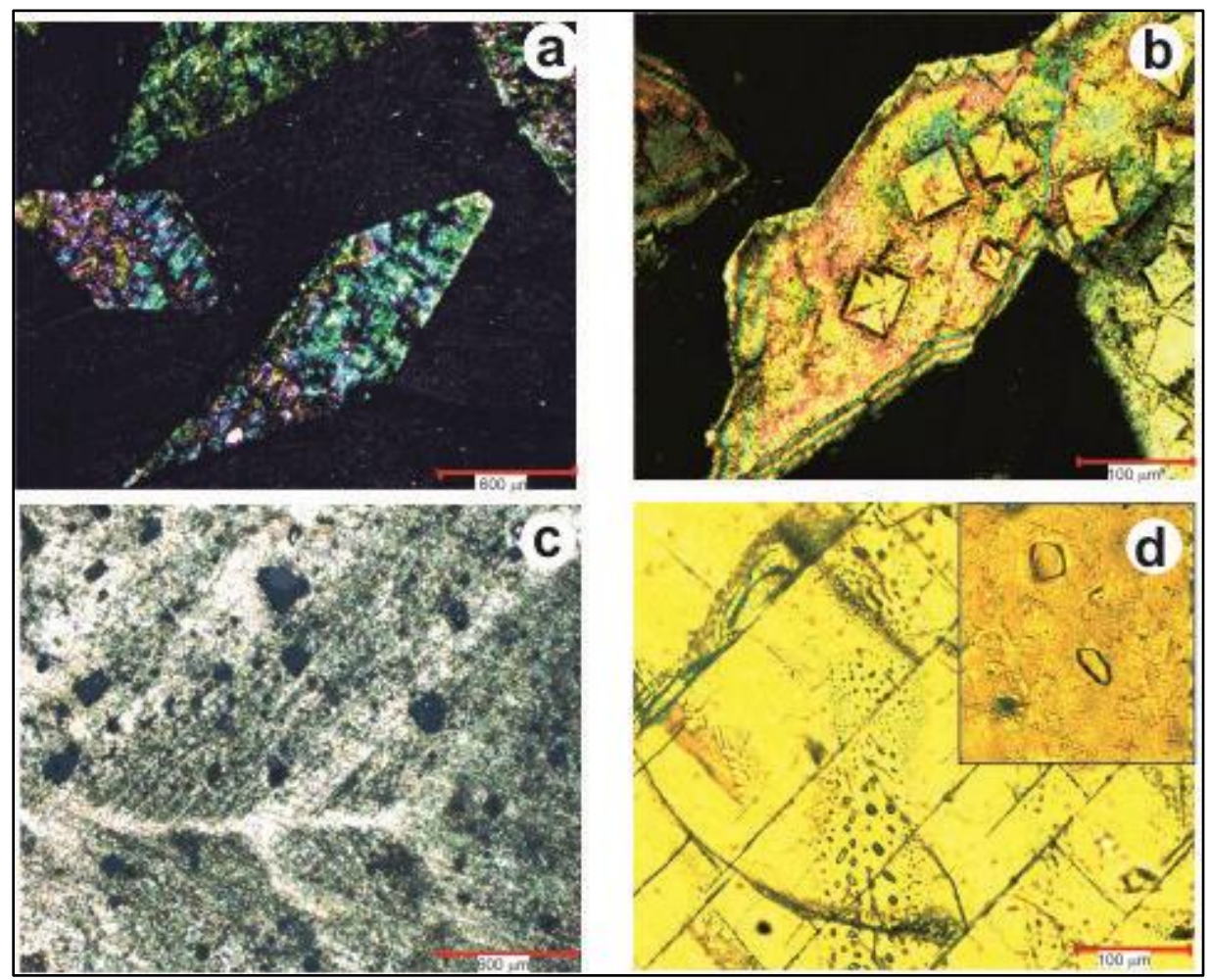

Figure 3. a) Euhedral glauberite and halite matrix, b) chevron texture, c) fluid inclusion, d) hopper halite.

The secondary marks were commonly observed in the drilling samples as the nodular structure anhydrite and mosaic texture of halite (Figure 2 and 3). The nodules form from displacively pore fluids which are concentrated at the capillary and upper of the phreatic zone and beneath of the sabkha surface. Diagenetic textures in most halite deposits are usually mosaic textures and mosaic halite (spar) which represent early burial period of salt deposits.

The glauberite mineral accompanying the halite mineral generally indicates increased periods of evaporation. At the same time, more dilute solution (including $\mathrm{Ca}$ ion), which input this medium, dissolves the precipitated halite mineral. Then, while the evaporation is continued, glauberite minerals precipitate in the newly formed solution.

$\mathrm{Na}$ and $\mathrm{Cl}$ content of pure halites varies from 37.0 to $39.5 \%$ and 37.7 to $41.0 \%$, respectively. $\mathrm{B}, \mathrm{Br}$ and $\mathrm{Li}$ content of the mineral range from 11.5 to $28.0 \mathrm{ppm}, 7.3$ to 11.0 $\mathrm{ppm}$, and 1.0 to $1.6 \mathrm{ppm}$, respectively. The ratios of $\mathrm{Cl} / \mathrm{Br}$ and $\mathrm{Na} / \mathrm{Br}$ in the halite minerals show very high values and the ratios were located on the halite dissolution-precipitation line but plotted in the direction of dissolution indicating that the element contents are related to dissolution and mixing process. 


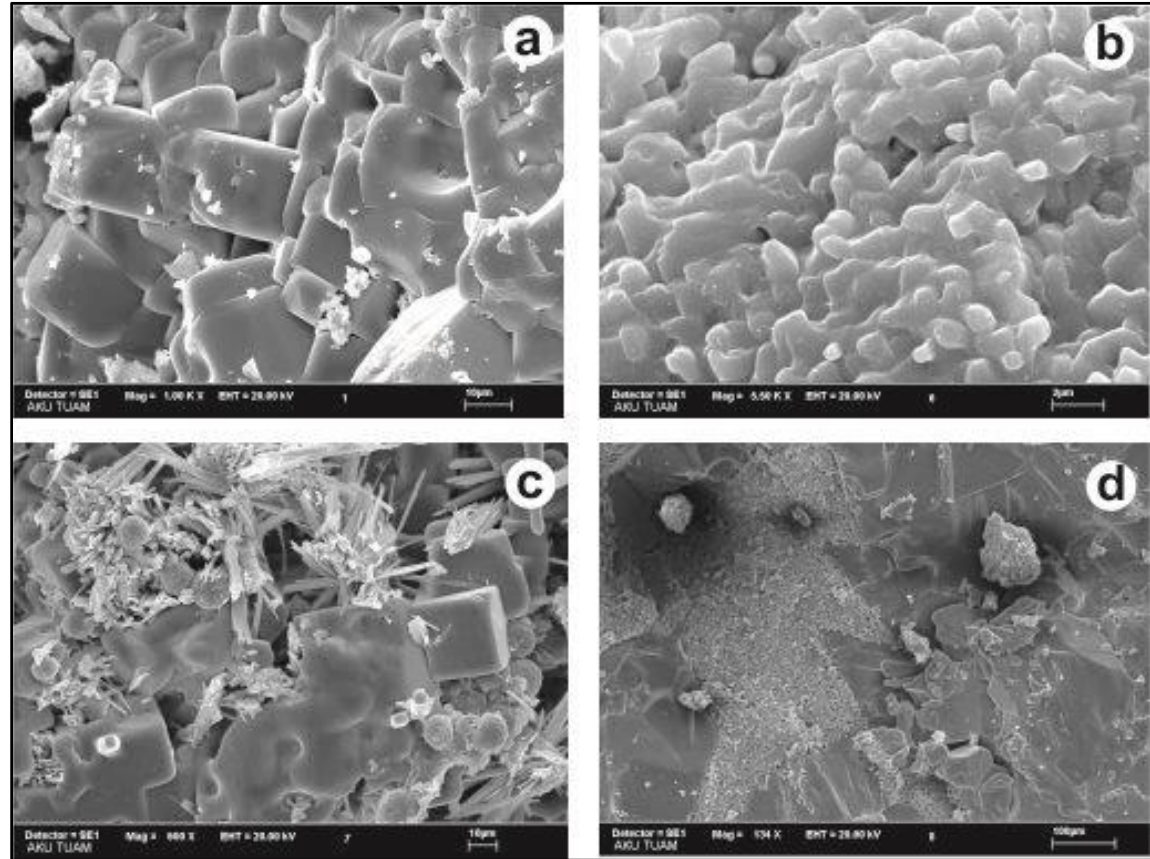

Figure 4. a) Euhedral halite, b) euhedral-subhedral halite, c) halite and radial shaped glauberite, d) euhedral glauberite and halite matrix

\section{Acknowledgements}

The project was funded by The Scientific and Technological Research Council of Turkey (TÜBİTAK 114Y629) and the Selçuk University Scientific Research Projects (16401034) support program.

\section{REFERENCES}

[1] Warren, K.J. Evaporite: Deposits, resource and hydrocarbons. Germany, 1041 p, 2006.

[2] Spence, R.J. \& Lowenstein, T.K. Evaporites: Geoscience Canada. Reprint Series, vol. 4, pp 141-164, 1990.

[3] Casas, E. Lowenstein, T.K., Spencer, R.J. \& Zhang, P. Carnallite mineralization in the nonmarine, Qaidam Basin, China; evidence for the early diagenetic origin of potash evaporites. Journal of Sedimentary Petrology, vol. 62, pp 881-898, 1992.

[4] Sönmez, İ. Glauberıte-Halite Association in Bozkır Formation (Pliocene, Çankır1Çorum Basin, Central Anatolia, Turkey). Bulletin of the Mineral Research and Exploration, vol. 149, pp 153-175, 2014.

[5] Davis, S.N., Fabryka-Martin, J. \& Wolfsberg, L.E. Variations of bromide in potable ground water in the United States. GroundWater, vol 42, pp 902-909, 2004.

[6] Freeman, J.T. The use of bromide and chloride mass rations to differentiate saltdissolution and formation brines in shallow groundwater of the Western Canadian Sedimentary Basin. Hydrogeology Journal, vol. 15, pp 1377-1385, 2007.

[7] Gürbüz, A. \& Kazanc1, N. Facies characteristics and control mechanisms of quaternary deposits in the lake tuz basin. Bulletin of the Mineral Research and Exploration., vol. 149, pp 1-18, 2014. 
[8] Yıldırım, C. Relative tectonic activity assessment of the Tuz Gölü Fault Zone; Central Anatolia, Turkey. Tectonophysics, vol. 630, pp 183-192, 2014.

[9] Fichtner, A., Trampert, J., Cupillard, P., Saygın, E., Taymaz, T., Capdeville, Y. \& Villaseñor, A. Multi-scale full waveform inversion. Geophysical Journal International, vol. 194, pp 534-556, 2013.

[10] Fichtner, A., Saygin, E., Taymaz, T., Cupillard, P., Capdevillee, Y. \& Trampert, J. The deep structure of the North Anatolian Fault Zone. Earth and Planetary Science Letters., vol. 373, pp 109-117, 2013.

[11] Göncüoğlu, M. C., Turhan, N., Şentürk, K., Uysal, Ş., Özcan, A. \& Iş1k, A. Orta Sakarya'da Nallıhan Sarıcakaya Arasındaki Yapısal Birliklerin Jeolojik Özellikleri. Maden Tetkik ve Arama Derleme Rapor No: 10094, Ankara (yayımlanmamış), 1996. 